\title{
La contribución de George Bernard Shaw en la lucha por los derechos de la mujer en la sociedad
}

\author{
George Bernard Shaw's contribution to the fight for \\ women's rights in society \\ Fuat Özkul ${ }^{1 \mathrm{a}}$ \\ İstanbul Aydın University, Turquia ${ }^{1}$ \\ D ORCID ID: 0000-0001-5519-47281
}

Recibido: 19 de enero de 2021

Aceptado: 01 de noviembre de 2021

\begin{abstract}
Resumen
El propósito de este artículo es analizar la defensa de los derechos de la mujer en un contexto moderno de machismo e injusticia, lo cual se cree que se ha iniciado desde el comienzo de la historia. En esta supuesta lucha por la igualdad, algunos especialista han sugerido que las mujeres siempre han sido el sexo oprimido y subordinado, mientras que los hombres han sido el grupo dominante, ya que tenían el poder de hacer leyes para dictar normas sociales y políticas con el fin de colocar a las mujeres en una esfera limitada. Esto, es una tendencia a pensar que los hombres dudaron en recurrir a la violencia con la intención de consolidar su dominio sobre el llamado "sexo débil". En este sentido, el estudio tiene como objetivo estudiar la contribución de George Bernard Shaw en la defensa de los derechos de las mujeres y ser consideradas libres y dignas, fuera de una condición de sometimiento.
\end{abstract}

Palabras clave: Masculinidad hegemónica, lucha por el poder, pro-feministas, feminismo shaviano, George Bernard Shaw, mujer

\begin{abstract}
The purpose of this article is to analyze the defense of women's rights in a modern context of machismo and injustice, which is believed to have started since the beginning of history. In this supposed fight for equality, some specialists have suggested that women have always been the oppressed and subordinate sex, while men have been the dominant group, since they had the power to make laws to dictate social and political norms to place women in a limited sphere. This is a tendency to think that men hesitated to resort to violence with the intention of consolidating their dominance over the so-called "weaker sex". In this sense, the study aims to study the contribution
\end{abstract}

${ }^{a}$ Correspondencia al autor:

E-mail: fuatozkul@stu.aydin.edu.tr 
of George Bernard Shaw in the defense of women's rights and to be considered free and dignified, outside of a condition of submission.

Keywords: Hegemonic masculinity, power struggle, pro-feminists, Shavian feminism, George Bernard Shaw, woman.

\section{Introduction}

During the Victorian period, when middle-class men's power reached its peak due to the natural consequences of the industrial revolution, the emergence of a prevalent problem which was conceptualized as the woman question might be seen as an inevitable result of the vulgar actions, unacceptable deeds and ill-mannered attitudes of men towards women. It has caused a lot of injustices and sufferings of especially women that paved the way to Women's Liberation Movement, because in woman, personal history blends together with the history of all women, as well as national and world history (Cixous, 1976). Historically and socially, the emergence of some resistance groups led by women who tried to struggle against the injustices caused by the accumulation of absolute power in the hands of patriarchy was not an unexpected phenomenon since most people, especially women, had been suffering under the tyranny of hegemonic men at the end of the $19^{\text {th }}$ century. Therefore, some anticipated movements that were particularly formed by women began to emerge as a reaction to these unbearable circumstances at the turn of the century a result of the unbearable consequences of the inadmissible masculine attitudes and practices which were the natural outcomes of the corruptive feature of power. Thus, a higher tension between the women and men occurred.

The relationship between masculinity and power is a complex and vague one as it cannot be easily noticed and differentiated from other types of power-related relations unless its practical applications are considered and observed carefully. However, it is crucial to study and analyze this correlation between masculinity and power as it determines most of the relations on the social scale such as the ones between men and men, and particularly the ones between men and women. In the introductory paragraph of his article "Men, Feminism, and Men's Contradictory Experiences of Power," Kaufman (1994) summarizes the relationship between men and power in a world dominated by men, the world of men is, by definition, a world of power. According to Kaufman, this power might be found anywhere and in every aspect of our social lives as it has become an inevitable part of our economic, political and social organizations. By this evaluation, Kaufman clarifies the point that the patriarchal-capitalist system is dependent on a clear-cut division of 
gender-marked values since when he mentions the men dominated world, he even neglects to point out the other half of humanity as if he was intending to say that this is a men's world and women have no place in it.

Foucault (1980) states a similar idea in Power / Knowledge, by pointing out that power is not something that can be owned, but rather something that acts and manifests itself in certain ways and practices. According to him; power is more 'a strategy' than a possession. Thus, it must be analyzed as something which is employed and exercised through a net-like organization and individuals are considered as the vehicles of power. In other words, Foucault sees it as a means, not as an end. Most people want to be powerful and use their different forms of practice in order to do what they want and behave as they like it. Additionally, Spence (2003) states that we are defined by how we use our power. Therefore, it is safe to say that it is the practices and applications of power which are acted out or implemented by people that cause oppression, subordination, and injustices, not the power itself.

In this case, power, whether practiced by exerting control and dominance forcefully or as suggested by Foucault (1978) by cultural and institutional means lawfully might have a positive impact on the people and lead to fruitful consequences for the whole society since Foucault emphasizes this point by stating the fact that where there is power there is resistance. Therefore, understanding power relations only as master-slave or oppressor - victim relations might be to falsify them, since these power relations between the individuals may be productive as they both suggest resistance.

Chomsky (2001) made an interesting point about this corruptive feature of power at a conference at Tufts University, by stating that it is only in folk tales, children's stories that power is used wisely and well to destroy evil. However, according to him, in the real world, the actual situation is quite different and people need to be totally ignorant and must be willing to neglect the corruptive quality of absolute power and its negative consequences for not feeling and noticing them. Fortunately, in the 19th century, not all women were so ignorant and uncultivated to accept this false premise about power. In contrast, they were conscious and experienced enough to conceive the facts of the world as they had already learned a lot of lessons from their misfortunes and acquired a lot of experiences from the painful lessons that the cruel world and its merciless masters had taught them so far. 
For Hoffer (1963), absolute power corrupts even when exercised for humane purposes. The benevolent despots seeing themselves as the shepherds of the humanity still demand the others the submissiveness of sheep. That is to say; even those well-intentioned rulers who hold the absolute power in their hands might unknowingly act in some particular ways so as to improve the life standards of the people might ruthlessly keep asking for more of it without even noticing its corruptive quality. Thus, seeing themselves as the shepherd of the weaker half of humanity, men have always expected women to be submissive and loyal to their rulers and law-makers, ask them to give their supports willingly to those who are already in power, and tried to train them to be and act as obedient and devoted citizens. Men must have power as the protector and the provider to save and protect them from possible external dangers and provide the best conditions and living standards for them.

By its part, Connell and Wood (2005) also stated that by the growth of industrial capitalism and the growth of imperialism" which leads to the hegemonic forms of masculinity. Thus, the patriarchal society became corrupted by the absolute power sanctioned by the church and other governmental institutions which are essentially used as pragmatic tools invented by the patriarchy itself for the sake of holding all the power in their hands to dominate and control women. Men used this power for their selfish purposes that result in women's imprisonment in their domestic sphere as a slave to their male masters.

This division between the feminine and masculine members of the society results in a serious issue, the question of equality which men and women have been fighting over since the beginning of history. Hence, it is crucial to examine the fundamental causes of this domination of men over women. Male-dominated ruling systems have always tried to put women in a position subordinate to men by declaring that submissiveness, physical weakness, vulnerability, passivity, and sentimentality are the innate female traits which are the natural causes of men's domination over women who are, on the other hand; logical, active, rational, and physically strong. These traits that are attributed to men constitutes a paradigm for masculinity that has made men superior to women. Therefore, to understand men's hegemony over women, it is vital to define what masculinity is. Masculinity is usually defined as the possession of the qualities traditionally associated with men.

These traditional traits are referred as the inspirational and standard ways of being and living as a natural-born man that, if not all, most members of that society approve of. Although 
masculinity is surrounding us everywhere it is almost indescribable. This is most probably because of the changeable quality of manliness or masculinity whose standards may vary due to the cultural differences, traditional expectations and patriarchal practices in various societies throughout the history since masculinity is a bit like air-you breathe it in all the time, but you aren't aware of it much (Dyer, 1985). Moreover, the difficulty of defining what masculinity is an apparent issue as there are no ready criteria to identify masculinities (Clatterbaugh, 1998). Yet, Connell (1995) has clarified the concept and decreased the level of the relativity of the studies about masculinities by developing the concept of an apparent hegemonic masculinity.

\section{Methodology}

As the basic goal of this paper is to understand and analyze how George Bernard Shaw as a prominent dramatist and thinker, contributed to women's emancipation in the defense of women's rights and whether or not Shaw might be considered to be a pro-feminist writer in the historical context. To this end, to accomplish the goals of this study, qualitative research method was used as it offers contextualization and interpretation of the data gathered by reviewing and rereading the works and articles written about the issue.

Therefore, to understand this purpose in the historical context and the contributions made by Shaw, the necessary data was obtained by rereading and reviewing the books, articles, research papers and speeches related to this subject. Hence, first of all, the historical causes of the women's liberation movements and why they had to revolt against the hegemony of men who had used and manipulated all the sources of power to consolidate their dominance was discussed by giving references to various sources that are particularly dealing with this issue. To clarify this, we can referring to Connell's categorization in her Masculinities (1995). Additionally, referring to Foucault's ideas in Power/Knowledge (1978), the relationship between power and resistance was analyzed to clarify the points that led to women's movements for liberating themselves. Hence, feminist waves and men's reactions to feminism was also examined and two major men movements, myhtopoetics and pro-feminists, were also included and discussed in this study as one of the main goals of this article is to illustrate George Bernard Shaw's contribution to women's emancipation in their fight for equality as a pro-feminist writer. 
Since this article is a part of social sciences that are inevitable and crucial for not only developing better conditions and a more democratic society but also for creating a better world for humanity, it includes different perspectives and a variety of interests, values and norms from different writers, scholars and literary critics in order to minimize bias and maximize the reliability of the data collected and analyzed. Thus, to provide meaningful and satisfactory answers to the aforementioned questions this methodology is deemed suitable, hence, preferred and utilized for this controversial and subjective issue.

\section{Results}

Since the beginning of history, men have been the dominant party in almost all societies as they had the political power to make laws in order to dictate the cultural, social, and political norms. Along with the political power, they have controlled the means of production by which they had the power to organize the societies by the social and religious institutions that were governed by the man-made rules to determine lifestyles and the fates of the majority of the population. They even did not hesitate to distort the social order for the purpose of sustaining their dominance and supremacy over the so-called "weaker sex." Cixous (1976), revealed this fact by claiming that men have committed the greatest crime against women.

Placing women to a limited sphere and fixing them in that position has been the most vital stage in constructing and maintaining patriarchal supremacy. Therefore, most of the rules and laws made by men were used to determine and regulate the relationships between the sexes. In addition to the man-made rules; sexual metaphors were also invented by men for the purpose of clarifying women's role and position as the secondary, lower, and weaker race as woman was made to believe that a well-adjusted normal woman has a divine composure (Cixous, 1976) since men have created "the classic representations of women as sensitive- intuitive- dreamy. Therefore, it is not possible for women to a self which is independent of the boundaries created by man by using the masculine rhetoric in a man-made world.

By the other hand, gender roles have been a deterministic factor in this struggle. Hence, maleness and masculinities might be dependent on some other different variables due to the places and situations they are exhibited and performed in. This point was searched and analyzed by Cornwall and Lindisfarne (1994) when they tried to explain how different types of masculinities are acted out in specific settings with respect to contested interpretations of power. They point out 
the ethnographic depictions of masculinity as an important factor in understanding the distinctive forms of masculinity which might be illustrated differently depending on the place and the circumstances where they are acted out. Thus, as they can be interpreted in different ways, it is not easy to define masculinities since they might be exhibited in a variety of forms in different locations, societies, and cultures. Therefore, to understand it accurately, ethnographic influences as well as the cultural, social and economic factors must also be taken into account carefully in terms of common methods they utilized in attaining, controlling and performing power.

\section{Discussion}

Hegemonic masculinity is a concept that provides the essential paradigm to support the typical dominant social position of men and the secondary position of women who have to lead a life subordinate to men. By this term, Connell (1995) tries to understand and explain how and why men assert and try to sustain dominant social roles over women, and additional gender identities, which are perceived as 'unmanly' or 'feminine' in a society. The next type she mentions is complicit masculinity which is the most common type of masculinity that can be observed in all of the male-dominated societies. It does not have all of the qualities of hegemonic masculinity, yet it does not challenge it, either. Thus, it may try to benefit from the role of fitting into hegemonic masculinity as it admires the qualities of hegemonic masculinity. Finally, protest masculinity is defined as a kind of marginalized masculinity that cannot depend on the privileges of hegemonic masculinity.

Female masculinity is another term used to describe a different type of masculinity coined by Halberstam (1998) who elaborates on the meaning of masculinity in terms of cultural, social, and political aspects as the different expressions of maleness. Halberstam claims that far from being an imitation of maleness, female masculinity actually provides a glimpse of how masculinity is constructed as a dominant social norm. Thus, it is formed as rejected scraps of dominant masculinity so that male masculinity may appear to be the real thing.

As there has been a shift from the gender orders of local societies to some global forms of masculinities, to understand the local masculinities better thinking globally is essential (Connell,1998). Thus, she asserts that a new version of masculinity has naturally emerged. This new type of masculinity does not require bodily forces as it mainly "depends on the traditional patriarchal dividend that provides the power and superiority which is accumulated by impersonal, 
institutional means" (Connell, 16). Since it is a mixture of corporate power and endless first-class travel, she terms it as "transnational business masculinity" which is very different from traditional bourgeois masculinity that mainly requires physical end economical force.

Moreover, depending on his findings from long term fieldwork among poor urban middleclass young men, Groes-Green (2009) clarifies the point that hegemonic form of masculinity is usually related to a privileged class in the society whereas subordinate ones mostly exhibit themselves via violence, or sexual relationship with their female partners. In his interviews with the unemployed young men, some of them confessed that the feeling of being a worthless man or feeling unmanly are the commonly shared emotions as they were constantly reminded that if they have no money they are worthless in the eyes of their female partners. However, it must be noted here that this local study may not be generalized to support the view that violence against women is only performed by young unemployed men.

Connell and Messerschmidt (2005) precisely described hegemonic masculinity as the currently most honored way of being a man, which ideologically legitimated the global subordination of women to men. Hence, it has already become a standard among men since most men have been trying to define and adapt themselves according to hegemonic forms of masculinity that are equated with heterosexuality and regarded as the acceptable and respectable forms of manliness (Connell, 1998). Therefore, a lot of men who lack the qualities of hegemonic masculinity have been trying to achieve these qualities which are accepted and approved of as the real components of being a real man in their societies. Consequently, Connell and Messerschmidt suggested that the practices of women and the historical interplay of femininities and masculinities must be researched by masculinity scholars more carefully (2005) because gender hierarchies are transforming due to the new forms and arrangements of female identities that have emerged as a result of the feminist movements.

\section{Shaw's contribution as a pro-feminist writer}

In the last two decades of the 19th century, a great variety of socialist movements came into existence mostly because of the influential theories originated from Das Capital written by Marx (1867). The Fabian Society, whose tactics were reforming and evolutionary rather than revolutionary, was one of the most influential socialist organizations that emerged in this era. George Bernard Shaw was among the influential members of this organization and, thus, he was called as a "Fabian feminist" by many literary scholars and critics of the 20th century such as 
Watson (1964), Lorichs (1973) and Weintraub (1977). In the opening lines of an essay The Irish Lady in Shaw's Plays, the feminist stance of Shaw is neatly elucidated: "Unlike most playwrights since Shakespeare, 'St. Bernard', the patron saint of the women's movement, wrote plays for strong, vital women who generate energy and motivate action” (Weintraub, 1980).

Watson (1964) also explained how Shaw could write such great roles for real women in his plays. In this article, he clarifies his perception of women by directly stating that "I always assumed that a woman was a person exactly like myself”' (p. 2). This response of Shaw makes it clear that he had never imagined women as different from his own self. Shaw was quite aware of the obvious fact that civilized women have artistic and intellectual impulses just as men have. Therefore, providing equal educational conditions and opportunities to women is vital to allow them to realize themselves by means of their artistic talents and intellectual capacities. Shaw acted in a quixotic manner for advocating women's rights and supporting them in all areas of social and political life, as Weintraub (1977) noted in the introduction to Fabian Feminist: "Shaw was as a veritable Don Quixote, supporting the weaker sex in all its struggles toward emancipation, and reserving all his contempt and satire for that sex which is generally considered the stronger" (p. 1). Shaw, while acting as a proponent of the woman's power struggle for liberating themselves, criticized the members of his own sex relentlessly with bitter humor.

Another significant Fabian feminist, Crane (1977), asserts that the female protagonists who were created by Shaw distinguished themselves from the other female characters on the British stage both by their reality and individuality. The fundamental features of Shaw's female characters reflect the changing reality about women's social and political status in the society as these traits included "self-awareness, self-evaluation, and a sense of personal worth" (p. 174) all of which are essential for the existence and acceptance of a self-dependent, liberated, modern woman figure who belongs to nobody but herself.

Shaw in the preface to Back to Methuselah (1921) summarizes his philosophy about the woman: "You are alive, and you want to be more alive. You want an extension of consciousness and power. You get them because you want them badly enough to keep trying for them until they come" (p. xxiii). In other words, noticing that the present conditions are not sufficient enough for them 'to be alive' and to realize themselves as independent individuals, women must demand additional qualities like consciousness and power from the bottom of their hearts. According to Shaw, if women demanded these 'additional organs' countlessly and kept struggling for them 
constantly, they would have the opportunity to create the appropriate conditions to get what they want and deserve eventually.

Influenced by Shaw's ideas, Chodorow (1978) defined gender differences and traits in the same way by considering that basic human characteristics and gender roles are acquired through the social duties and tasks that have been assigned to them. Hence, in performing some certain roles such as maternity, these dictated duties result in determining their gender qualities and roles. She claims that the acceptance of 'mother role' causes most women to cancel their individuality and accept passivity as a normal mode of behavior. Hence, if women want to change their subordinated positions, they must refuse these dictated duties and form new roles and duties, and keep demanding and struggling for them to gain their respectful positions and equal rights in the society.

The transformative impact of the Suffrage movement that has had a significant role in changing the definitions of sexuality and gender roles was notably important and valuable. This point, as noted in Bernard Shaw: A Reassessment was succinctly summarized by Shaw: "People are still full of the old idea that woman is a special creation" (Wilson, 1969). Thus, he claimed that women have been trying to change that false assumption about themselves lately to make people, especially men, understand that a woman is really only a man in petticoats, or if you like, that a man is a woman without petticoats. For Shaw, the type of women he approved of is not different from men. Actually, they are just like men with a few minor physiological differences. Hence, if men want to create a better world and a prosperous civilization both for themselves and the other members of the society, they had to give women their natural rights as perfect equals of men since women's role is a monitor of transformation and development for all the members of society regardless of their sexes.

As for the limitations of this study, although many different studies and a great variety of sources regarding the masculinity studies, feminist waves and George Bernard Shaw have been searched and analyzed to support the points made in this article, it must be noted here that they were all reread and interpreted from a subjective point of view. This is because to accomplish the goals of this study, qualitative research method was used as it offers contextualization and interpretation of the collected data. Thus, the author of this article is totally aware of the subjective nature of the discussion and the findings of this study as it is not possible to gather more scientific and objective information by using quantitative method that might reduce the subjectivity, 
minimize bias and maximize the reliability of the data collected and analyzed. To this end, it is safe to acknowledge that all the arguments and assertions made in this article might be, and perhaps should be evaluated and interpreted from different perspectives by other scholars and researchers as well. Therefore, this study demands and recommends further studies on Shaw, to clarify whether or not he might be accepted as a pro-feminist writer, and whether or not he made any contributions to the fight for women's rights in society

\section{Conclusion}

Although Shaw himself never claimed to be a feminist overtly, he contributed a lot to the women's emancipation in his particular way of understanding and dealing with the problems of the women of his time in his dramatic and non-dramatic works. Thus, considering and accepting Shaw as a pro-feminist writer might not be nonsensical at all. Since Shaw's theory has a fundamental potential for feminism, one can argue that, like other human traits, sexual characteristics and roles might be socially constructed as well.

As a last word, it is high time that men, without the fear of losing their privileges and exclusive rights, must pave the way for women to enter all the areas in the public sphere by providing completely equal social, educational, financial and political rights and opportunities to their spouses, mothers, and daughters to let them have their due share in solving the problems by cooperating with them willingly so as to create a more livable world and a better future for all the people regardless of their genders and sexes.

\section{References}

Bly, R. (1991). Iron John: A Book about Men, Shaftsbury, Dorset: Element.

Chomsky, N. (December 8, 2001). 'The World After September $11^{\text {th' }}$, American

Friends Service Committee. Conference at Tufts University, Massachusetts.

Chodorow, N. (1978). The Reproduction of Mothering: Psychoanalysis and the

Sociology of Gender. London: California UP.

Cixous, H. (1976) The Laugh of the Medusa. Signs, 1 (4), The University of Chicago Press, 875893. http://www.jstor.org/stable/3173239 in April 2021.

Clatterbaugh, K. (1998) Contemporary Perspectives on Masculinity: Men, Women and

Politics in Modern Society. Colorado, USA: Westview. 
Connell, R.W. (1995). Masculinities. Sydney: Allen \& Unwin.

Connell, R. W. (1998). Masculinities and globalization. Gender, Men and Masculinities, 1 (1), 323. https://journals.sagepub.com/doi/10.1177/1097184X98001001001

Connell, R.W. \& Messerschmidt, J.W. (2005) Hegemonic Masculinity: Rethinking the Concept. Gender and Society, 19, 6, 829-859. https://journals.sagepub.com/doi/10.1177/0891243205278639

Connell, R. W. \& Wood, J. (2005). Globalization and Business Masculinities. Men and Masculinities, 7 (4), 347-64. https://citeseerx.ist.psu.edu/viewdoc/download?doi=10.1.1.1028.7503\&rep=rep1\&type $=p$ $\underline{\mathrm{df}}$

Cornwall, A. \& Lindisfarne, N. (1994) Dislocating Masculinity: Comparative Ethnographies. London: Routledge.

Dyer, R. (1985). 'Male Sexuality in the Media' in A. Metcalf and M. Humphries (eds.) The Sexuality of Men, London: Pluto.

Edwards, T. (2006). Cultures of Masculinity, London \& New York: Routledge. Foucault, M. (1978). The History of Sexuality. New York: Pantheon.

Foucault, M. (1980). Power/Knowledge: Selected Interviews and Other Writings 1972-1977 London: Harvester Press.

Groes-Green, C. (2009). Hegemonic and Subordinated Masculinities: Class, Violence and Sexual Performance Among Young Mozambican Men’. Nordic Journal of African Studies, 18 (4), 286-304. http://www.njas.helsinki.fi/pdf-files/vol18num4/groes-green.pdf

Halberstam, J. (1998). Female Masculinity. Durham: Duke University Press.

Hoffer, E. (1963). The Unnaturalness of Human Nature. New York: Harper \& Row. Hunt, K. (1986). Crossing the River of Fire: The Socialist Construction of Women's Politicization. Feminism and Political Theory. London: SAGE Publications.

Kaufman, M. (1994). 'Men, Feminism, and Men's Contradictory Experiences of Power'. H. Brod and M. Kaufman (eds) Theorizing Masculinities, Thousand Oaks, California: SAGE Publications.

Kimmel, M. S. (1987) 'Men's Responses to Feminism at the Turn of the Century'. Gender and Society, 1 (3), 261-283. 


\section{https://doi.org/10.1177/089124387001003003}

Kimmel, M. S. \& Kaufman, M. (1994). Weekend Warriors: The New Men's Movement.

H. Brod and M. Kaufman (eds) Theorizing Masculinities, Thousand Oaks, California: SAGE Publications.

Moore, R. \& Gillette, D. (1990). King, Warrior, Magician, Lover: Rediscovering

the Archetypes of the Mature Masculine. New York: Harper Collins Publishers.

Schrock, D. \& Schwalbe, M. (2009). Men, Masculinity and Manhood Acts.

Annual Review of Sociology, 35, 277- 295.

https://www.annualreviews.org/doi/abs/10.1146/annurev-soc-070308-115933

Shaw, G. B. (1921). Back to Methuselah: A Metabiological Pentateuch. London: Constable and Company.

Shaw. G. B. (1955). 'The Womanly Woman'. Major Critical Essays. The Quintessence of Ibsenism. The perfect Wagnerite. The Sanity of Art. London: Constable and Company Ltd.

Spence, Gerry. (2003). Essay on the Use and Abuse of Power. 12-25. https://gerryspence.com/the-rat-hole/

Watson, B. B. (1964). A Shavian Guide to the Intelligent Woman. London: Chatto \& Windus.

Weintraub, R. (Ed). (1977). Fabian Feminist: Bernard Shaw and Woman. Pennsylvania: The Pennsylvania State University Press.

Weintraub, R. (1980). The Irish Lady in Shaw's Plays. Shaw Review, 23 (2), 77-89. https://www.jstor.org/stable/40682605

Wilson, C. (1969). Bernard Shaw: A Reassessment. London: Hutchinson \& Co Ltd. 